\title{
The Loss of Hope in Postcolonial Kenya in \\ Ngugi Wa Thiong'o's Petals of Blood (1977) \\ Noha Abdelaziz
}

\begin{abstract}
Kenya is one of the African countries that suffered from the colonization of the white settlers for many decades. After its independence in 1963, it was supposed that Kenya would enjoy a good life full of liberty, justice and welfare. But this was not the real fact. The British colonizers hand over the power of the country to a faction of a dominant group in order to ensure that this faction of people will be their allies rather than their enemies.

Consequently, the Kenyan people after independence suffered from a new period of exploitation, oppression and covetousness. But according to the Kenyan people, this new period of time was slightly different and complicated from that of the British one, because exploitation and suppression were practiced by indigenous people rather than foreigners.

Thus, its influence over the Kenyans became dire and crucial.

This research aims at demonstrating the different strategies of hegemonic reign adopted by the black elite who undertake the rule of Kenya after the foreign settlers. Through adhering to the policy of consummate hegemony, the black rulers could double the suffering of the Kenyan masses and ruining their long-lasting hope for a liberated and better life. Out of Gramsci, Ashcroft, Griffiths, and Tiffin's analysis of the concept of Hegemony, the research will exhibit the various aspects of the hegemonic power and its resulted images of corruption and oppression through handling Ngugi Wa Thiong'o's Petals of Blood.
\end{abstract}

The history of the term hegemony goes back to the time of the Ancient Greece where it had an initial meaning denoting the dominance of a city state over city states. In the twentieth century, the term has been adopted by the Italian Antonio Gramsci who defined the term of hegemony as being the control of one dominant class over the means of production. About the term of hegemony according to Gramsci, Sir Peter Ives confirms:

Before Gramsci, the term 'hegemony' was more or less limited to meaning the predominance of one nation over others, especially within relatively friendly alliances. Significantly due to his writing hegemony is now used to describe the intricacies of power relations in many different fields from literature, education, film and cultural studies to political science, history and international relations. In a nutshell, Gramsci redefined hegemony to mean the formation and organization of consent. (2)

Antonio Gramsci (1891-1937) who was one of the political theorists and cultural critics celebrated in the twentieth century and a member of the Communist Party in Italy stressed the notion of hegemony by consent or persuasion. According to him, the group or the ruling class dominates the whole systems of the country not through direct coercion but through persuading the masses that it comes to rule in order to be at their service. Consequently, Gramsci maintains that the:

Government [is] by consent of the governed, but an organized consent, not the vague and generic kind which is declared at the time of elections: the state has and demands consent, but it also 'educates' this consent through political and trade-union associations which, however, are private organisms, left to the private initiative of the ruling class. [Brackets mine] (153) 
Through the persuasive policy of hegemony or as Gramsci calls it, the hegemony by consent, the subordinates begin to be convinced that the ruling class seeks to achieve their welfare and raise their standard of living; hence, they welcome its dominance and control.

The same connotation of the term hegemony used by Gramsci was almost adopted by Ashcroft, Griffiths, and Tiffin. They also stress the crucial role of the ruling class in controlling the proletariats and monopolizing different aspects of living. Hegemony according to Ashcroft, Griffiths, and Tiffin can be defined as:

The power of the ruling class to convince other classes that their interests are the interests of all. Domination is thus exerted not by force, nor even necessarily by active persuasion, but by a more subtle and inclusive power over the economy, and over state apparatuses such as education and the media, by which the ruling class's interest is presented as the common interest and thus comes to be taken for granted. (116)

Through handling the term of hegemony by the theorists Antonio Gramsci, Ashcroft, Griffiths, and Tiffin, it becomes apparent that the meaning of the term answers the question of why the proletariats' class agrees to be suppressed and exploited by the dominant class and why the latter enjoys playing that role. "Among all the different possible meanings for the term [hegemony], one common clement is that it helps explain why large groups of people continually acquiesce to, accept and sometimes actively support governments- and entire social and political systems- that continually work against their interests" (Ives 6).

One of the postcolonial writers who devoted most of his various writings for discussing and criticizing the outcomes of the national elite's blind hegemony in Kenya after independence is Ngugi Wa Thiong'o. He is a Kenyan dramatist, novelist, essayist and short story writer who was born in January 5, 1938, in Limuru, Kenya. He is currently a distinguished Professor of English and Comparative Literature as well as the Director of the International Center for Writing and Translation at the University of California, Irvine. He is considered one of the most effective African writers whose works have contributed in the enrichment of the African history and culture. They have also played a very important role in criticizing the effects of the Western colonization and its subjugation of the African cultures, and the oppression of the later African nationalists of the poor masses.

Among Ngugi's greatest fictional works is Petals of Blood. It is his last novel that was written in English language. In this novel, Ngugi explores the simple rural life of a village that is attacked suddenly by the monster of capitalism and modernism. He presents a serious image of some irresponsible leaders who are assumed responsible positions, and nonetheless they fail to cope with the daily hardships of the people. Through adopting capitalism as the major strategy of their hegemony, the ruling elite dominate the different apparatuses of the country. "Additionally, the novelist is equally concerned about the system of governance that will ensure that every individual in Kenya enjoys the fruit of a true and complete independence. Ngugi does not support capitalism as the system of governance suitable for Kenya and for Africa in general".(Addei, Osei and Annin 164). Hence, Petals of Blood "is a dramatization and condemnation of the ruthless capitalist exploitation of the masses by those in privileged positions in independent and 'free' Kenya" (Addei, Osei and Annin 164).

The politicians and other ruling people of Illmorog are depicted in the novel to be extremely successful in neglecting the village and its people, and their trials to change the village into the worst are clearly represented. As days pass, the village of Illmorog is 
afflicted with severe drought and thirst that people cannot find what to eat. Consequently, the four characters; Munira, Abdullah, Karega and Wanja decide to lead the villagers to the city of Nairobi where they can meet their MP to find a solution for his people. They have a great hope in the MP that he will take the matter into his consideration, so Karega says "...And who is an MP? Isn't he the people's voice in the ruling house? He cannot ignore us. He cannot refuse to see us?" (Wa Thiong'o 152). Unfortunately, the reaction of the MP was unexpected. He appeared to the masses that began to applaud feeling joy and glory that their MP appreciated their existence and would respond to their requests. But the MP, after listening to their complaints, answers:

Now, I want you to go back to Illmorog. Get yourselves together.

Subscribe money. You can even sell some of the cows and goats instead of letting them die. Dive deep into your pockets. Your businessmen, your shopkeepers, instead of telling stories, should contribute generously. Get also a group of singers and dancers - those who know traditional songs ... Our culture, our African culture and spiritual values, should form the true foundation for this nation. (Wa Thiong'o 218)

Actually, the reaction of the MP towards the people of Illmorog emphasizes his indifference, trivial solutions and his desire to escape from the responsibility. He represents a living example of the corrupt and perverse MP who is craving to realize his self interests using all available means. He does his best to collect the votes of Illmorog's people during the elections, and when he succeeds in the elections, he does not pay any attention to his constituency. Even the people of Illmorog do not know his name and cannot remember his shape. They hardly can remember his arrival from time to another to collect the votes for the sake of elections. This fact is clearly stated through the novel where "... Some could not remember his name. They had heard of him during the last elections. He had visited the area to ask to be given votes. He had made several promises. He had even collected two shillings from each household in his constituency for a Harambee water project, and ranching scheme. But they had hardly seen him since" (Wa Thiong'o 22-3). Not only does the MP neglect the responsibilities of his constituency, but he also exemplifies another example of the cunning swindler who convinces the poor people to pay some amount of money for the benefit of making a water project, and after some time they discover that the fake project is just nonsense. Nderi Wa Riera exploits the money of the needy peasants in attaining some loans through which he can make some personal projects and therefore achieve his dream of an endless wealth. The scandalous image of the MP is clearly conveyed through Addei, Osei and Annin's comment:

Ngugi further presents people in authority and therefore in responsible positions as being irresponsible who have more or less betrayed the cause for which they are put in such positions of authority. Nderi Wa Riera, Member of Parliament for Illmorog is portrayed as an irresponsible MP and he is symbolic of other MP's who are equally irresponsible. Nderi Wa Riera visits his constituency only when he is soliciting for votes during elections. He is also fraudulent. He collects money from some members of his constituency to use for a Harambee water projects which never materialize; rather he shamelessly uses the money to secure a loan for his selfish gains. Like other MP's, Nderi Wa Riera misuses his privileged positions to amass wealth for himself at the expense of the peasant workers. (167) 
As a result of the Illmorogians' sudden visit to the MP, he decides to develop their village. His plan of development begins with erecting church building and a police post. Then he proposes to make a shopping center at Illmorog, so "A few acres of land would of course be taken from the people for the purpose, but the Country Council would pay adequate compensation" (Wa Thiong'o 317). This series of progressive projects makes the Illmorogians feel that they will live for the first time, a life similar to that of the civilized city. Consequently, they begin to invest their lands and get loans from the African economic bank established in the village. But after a short time, this plan of trade and progress proves its failure because:

... a whole lot of peasants and herdsmen of Old Illmorog who had been lured into loans and into fencing off their land and buying imported fertilizers and were unable to pay back were similarly affected. Without much labor, without machinery, without breaking with old habits and outlook, and without much advice they had not been able to make the land yield enough to meet their food needs and pay back the loans. Some had used the money to pay school fees. Now the inexorable law of the metal power was driving them from the land. (Wa Thiong'o 326-7)

It is apparent that the MP exploits his people's kindness and their little knowledge of trade and progressive projects, so he tempts and convinces them to invest their money and lands in order to become one of those good businessmen. In addition, this kind of development initiated by the MP is considered, according to the people of Illmorog, another form of the preceding colonization because it carries with it all the elements that existed during the British colonization.

Furthermore, the monopoly of the Theng'eta project by the three black managers; Chui (the headmaster of Illmorog School), Mzigo (the administrator of Education branch in Illmorog) and Kimeria (the ill-mannered businessman) is an intelligible example of the Kenyan ruling class corruption and their desire to dominate everything for their sake. The term Theng'eta is basically attributed to a drink made of some seeds. This drink is made for the first time by Nyakinyua, an esteemed old woman in the village who was famous for her performing and adhering to all traditional rituals in the village. On the day of circumcision, the people of the village were celebrating this day by practicing some African rituals and drinking Theng'eta. After some time, the drink of Theng'eta became the basic drink in the shop of Abdullah in which Wanja was also working as a barmaid. But after the monster of modernism had covered all Illmorog, the three African managers found that the drink of Theng'eta became famous and loved by all people, so they decided to adopt this project by themselves. Now in the New Illmorog, the drink of Theng'eta becomes manufactured in a great factory of brewing Theng'eta and changes from just a native drink used by people mostly in ceremonies to be one that is sold to international markets. This kind of exploitation and monopoly of the poor villagers' ideas and efforts is enhanced through Patrick Williams' words:

Interest in Illmorog is also fuelled by Theng'eta, the potent ritual drink made for the village festival by Nyakinyua, subsequently sold on a small scale by Wanja and Abdullah, and later turned into a debased, massproduced substance, manufactured in an industrial complex employing hundreds and sold to an international market. ... it is in fact a good illustration of the Marxist argument about the way in which capitalism turns use value (Theng'eta made with care by people for their own use in important community ceremonies) into exchange value (Theng'eta 
commercially produced simply as a commodity to be sold for the greatest possible profit). (83)

The monopoly of the Theng'eta drink in Illmorog was a great shock for all the villagers because they all know that Nyakinyua is the first one who invented it. Moreover, a formal statement has been issued by the main directors of the Kenyan branch of brewing Theng'eta; Chui, Mzigo and Kimeria, that forbids the making of Theng'eta drink by anyone outside this supposed factory.

In fact, the policy of the Kenyan governors in Petals of Blood proves to be the same one used by the former British colonizers. The black rulers create for themselves a special society in which the laws are conveyed and changed according to their self-interests; a society in which the rich live on the expense of the poor's sweat. According to Karega in petals of Blood, "This was the society they were building: this was the society they had been building since Independence, a society in which a black few, allied to other interests from Europe, would continue the colonial game of robbing others of their sweat, denying them the right to grow to full flowers in air and sunlight" (Wa Thiong'o 348-9). So, in petals of Blood, Wa Thiong'o tries to draw the reader's attention to the nature of the capitalistic system, its danger and its effects upon people and the country as a whole. He also stresses the great efforts of the peasants and workers to regain the independence of their country and how their revolution had been stolen by some few persons who alleged their sincerity and loyalty to the nation and their ability to fulfill the people's hopes. Thus, as Jurgen Martini confirms:

The main effect of the particular neo-capitalist system as outlined in petals of Blood is that it divides the now independent society into a small minority of property owners and a large mass of peasants and workers that although it was mainly their fight which helped to bring about the end of the colonial system are completely left out of the running of society's affairs and whose position becomes more and more desperate with the development of industrial capitalism. (288)

The effect of depriving both Wanja and Abdullah of the license of Theng'eta's liquor was very devastating. Wanja and Abdullah have no other source of livelihood except this bar that became famous for brewing Theng'eta liquor in New Illmorog. Both characters are forced to confront an unknown fate. Wanja's look towards the world becomes extremely different. She intended to adopt a different logic of life. She tells Karega that "This world ... this Kenya ... this Africa knows only one law. You eat somebody or you are eaten. You sit on somebody or somebody sits on you" (Wa Thiong'o 345). As a result, Wanja is driven to prostitution and converts her house to a whorehouse in which she was receiving many different kinds of people in return for a good amount of money. Indeed Wanja:

Unwilling to be pushed into the quagmire of poverty and destitution by this invasion of Mammon, she becomes a convert to the creed of "eat or be eaten," and open her whorehouse, the Sunshine Lodge. When she receives Munira in the Lodge she charges a fee of one hundred shillings. This is the apotheosis of the New Kenya in which "nothing is free" and no other nexus is left remaining between man and man "than naked selfinterest, than callous cash payment." (Sharma 298)

On the other hand, the handicapped Abdullah becomes a vagrant and cannot find an alternate job. He tries to work at anything, but finally he could not comply with the current nature of the independent Kenya. Based on Addei, Osei and Annin's opinion: 
... Abdullah's effort to remain in business proves futile as he cannot cope with the aggressive and rigorous competition. It is indeed capitalist exploitation in that the few rich authority employ various means to take the few possessions of the poor which they add to their already full baskets of possessions. Like a greater percentage of the masses, he descends to the lowest rung of the social ladder-he falls from a prosperous, genuine businessman to a drunken wretch now inhabiting a room in a mud walled barrack of a house. From the supermarket nearby, the workers take things on credit and do not pay in time and his stock consequently decreases so he reduces to a seller of sheepskins and fruits by the way side. He is reduced to almost a beggar. (166)

Actually, the penetration of capitalism into the village of Illmorog leaves a great effect upon almost all the people of the village. Beside Wanja and Abdullah, "... the bewildered and deceived peasants, unable to match the business acumen and financial standing of the big men from the city, inevitably lose their lands and all their possessions and helplessly degenerate into laborers or worse" (Palmer 275)

In addition, the characters of both Chui and Mzigo in the novel contribute highly in the corruption of the educational system. Kenyan citizens after independence imagined that the Kenyan schools would return to its authenticity, would concentrate upon studying the different subjects in African language and would not surrender again to the hegemony of the European culture. But the contrast is what happens during the rule of the black leaders. For example, Chui who previously was a student at European Siriana School and who led a strike before at the same school, is now the headmaster, but his policy became completely changed after independence."He did not therefore want to hear any more nonsense about African teachers, African history, African this and that: whoever heard of African, Chinese, or Greek mathematics and science? What mattered were good teachers and sound content" (Wa Thiong'o 206). Chui does not pay any attention to the African culture or the desire of the students to study and think in African. Even when the students led a strike in order to be learned in African, "Chui called in the riot squad" which, was "led by a European officer" and all the students had been "dispersed with a few broken bones and skulls" (Wa Thiong'o 207).

Furthermore, during the rule of the black governors, nothing new had been added to the Kenyan schools. The schools continued to be poorly equipped and poorly developed as they were during the rule of the British colonizers. The school of Illmorog in particular which was under the management of Mzigo was a deserted school with no teachers or even pupils. The children in Illmorog felt the negligence of the managers towards their school, for the school was constantly without teachers or suitable equipment, so they had no motive to go to it. Mzigo himself knows this fact and does not deny it. When Munira firstly comes to Illmorog and finds no teachers or pupils in the classes, he returns to Mzigo in order to complain, but Mzigo answers him saying "I thought you wanted a place of peace" and then he confesses "I honestly don't know what's wrong with that school. No teacher wants to stay there" (Wa Thiong'o 15). Ironically, Mzigo, the responsible manager, confesses that there is a problem with Illmorog School and however, he did not even try to solve it.

In fact, people did not feel any kind of change or improvement of the educational system during the management of the black leaders. The black leaders were longing for filling their pockets with money using any available means. They did not think about improving the level of their African schools in order to attract the good African teachers to 
work in. Hence, the African teachers were naturally directed to other foreign schools as they were paid well there and could work in a respectable atmosphere.

Related to other issues of economic and educational corruption portrayed through the novel, is the issue of ethical corruption. The blind hegemony of the black leaders makes them enslave the needy masses and exploit their hardships for their personal inclinations. Kimeria is one of the country's businessmen and a friend to the MP. He is excellent in using the art of exploitation. In the past, he cheated Wanja and ruined her life. When she became pregnant, he abandoned her to face her disgraceful fate. Now, when the delegation of Illmorog meets him in order to ask help for the sick child and meet the MP, Kimeria uses the same weapon of compulsory exploitation. He asks to meet Wanja alone. When she confronts him face to face, he seduces her for the second time forgetting his villainy in the past. As Wanja refuses his request, he threatens to imprison her and all the other people coming with her.

Actually, the character of Kimeria reflects significantly a side of the political and moral corruption in which Kenya lived after independence. Kimeria is a politician and a successful businessman, but he has the morals of a scoundrel and a villain. He bargains with Wanja and puts his help in one pan of a balance, and the act of adultery in the other one. He equals an act of humanity with an act that is contradictory to religion and ethics. Instead of using his authority in helping the people and solving their problems, Kimeria uses the authority in threatening and exploiting them. According to Kathleen Greenfield:

Hawkins Kimeria is perhaps the most fully drawn of the villains in this novel. He has seduced, impregnated and abandoned Wanja, then on the journey to Nairobi, extorted sex from her in exchange for freedom. Before that, he betrayed Abdullah and by extension the independence movement. He lives in the Blue Hills, home of the former colonial oppressors of Kenya. In large measure he has simply stepped into the shoes of those oppressors, but with the added guilt produced by hypocrisy - the pretense of being one of the people while preying on the unsuspecting like a hyena and of indulging his basest appetites under the cover of propriety and respectability. Kimeria and others thus represent not only economic oppression, but moral depravity as well. (36)

The desire to achieve the rapid wealth and authority can blind the hearts, lead the brains astray, and make the people who adore this inclination have no ability to distinguish between the ill-gotten gains and the legal ones. In Petals of Blood, the characters of Nderi Wa Riera, Chui, Mzigo and Kimeria represent an example of those who achieve their goal of reaching the power of hegemony. However, they succeed truly in destroying their people's hope of a noble life. According to Patrick Williams "The postcolonial bourgeoisie which constitutes the new ruling class in both economic and political terms is responsible for the wholesale betrayal of the hopes of the newly independent nation, the practical possibilities which independence offered, and the ideals of the national liberation struggle" (83).

Conspicuously, Ngugi in Petals of Blood presents a reflective picture of the status of Kenya after independence. The indigenous rulers hang on to power forgetting about the requirements of the miserable citizens who blessed their coming to reign thinking that they will be merciful than the previous white colonizers. The effect of such hegemonic power is really scandalous and it can lead to destroying not only the people's hopes but also their culture, aims, ambitions and even their sense of belonging. Actually, Kenya is 
just an example of other African countries that were and are still living under the absolute hegemony of their unscrupulous heads.

\section{Works Cited}

1. Addei, Cecilia, Cynthia Osei and Felicia Annin. "Ngugi and Postcolonial Africa: History, Politics and Morality in Petals of Blood and Matigari." International Journal of Scientific \& Technology Research. Vol.2, Issue 9. September 2013. Web. 12 July 2015.

2. Ashcroft, Bill, Gareth Griffiths, and Helen Tiffin. Post-colonial Studies: The Key Concepts. London \& New York: Routledge, 2000. Print.

3. Gramsci, Antonio. Prison Notebooks. New York: Columbia UP, 1992. Print.

4. Greenfield, Kathleen. "Murdering the Sleep of Dictators: Corruption, Betrayal and the Call to Revolution in the Works of Ngugi Wa Thiong'o". The World of Ngugi Wa Thiong'o. Ed. Charles Cantalupo. Trenton: Africa World Press, Inc., 1995. Print.

5. Ives, Peter. Language \& Hegemony in Gramsci. London: Pluto P, 2004. Print.

6. Killam, G.D., ed. Critical Perspectives on Ngugi Wa Thiong'o. Washington: Three Continuous P, 1984. Print.

7. Martini, Jugen. "Ngugi Wa Thiong'o: East African Novelist." Killam 285-291.

8. Palmer, Eustace. "Ngugi's Petals of Blood." Killam 271-284.

9. Sharma, Govind Narain. "Ngugi's Apocalypse: Marxism, Christianity and African Utopianism in Petals of Blood." Killam 292-304.

10. Wa Thiong'o, Ngugi. Petals of Blood. New York: Penguin Group, 1977. Print.

11. Williams, Patrick. Ngugi Wa Thiong'o: Contemporary World Writers. Manchester \& New York: Manchester UP, 1999. Print. 